\section{Decreased active TGF- $\beta 2$ levels in the aqueous humour during immune reactions following penetrating keratoplasty}

P Maier, A Broszinski, U Heizmann and T Reinhard

\begin{abstract}
Purpose The secretion of transforming growth factor (TGF)- $\beta_{2}$ into the aqueous humour is important for maintaining the immunological privilege of the anterior ocular segment that promotes corneal allograft survival. Levels of total TGF- $\beta_{2}$, however, were similar in eyes with and without immune reactions following penetrating keratoplasty (PK). In this study, we tested the hypothesis whether the activated form of TGF- $\beta_{2}$ is decreased in eyes with immune reactions following PK.
\end{abstract}

Methods Anterior chamber puncture was performed in 38 cataract patients without PK (group I), in 10 patients without immune reaction following PK (group II), and in 10 patients following PK with newly diagnosed endothelial immune reaction (group III).

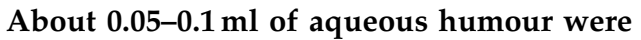
harvested from each patient. Analysis of active TGF- $\beta_{2}$ was started via ELISA within $3 \mathrm{~h}$ following puncture.

Results Average active TGF- $\beta_{2}$ concentration was $38.9 \mathrm{pg} / \mathrm{ml} \pm 24.3$ in group $\mathrm{I}, 47.4 \mathrm{pg} /$ $\mathrm{ml} \pm 23.1$ in group $\mathrm{II}$, and $12.7 \pm 26.0 \mathrm{pg} / \mathrm{ml}$ in group III. The differences between groups I and III $(P=0.005)$ and groups II and III $(P=0.008)$ were statistically significant.

Conclusion The lowest levels of active TGF- $\beta_{2}$ were measured in eyes with newly diagnosed endothelial immune reactions. This suggests that TGF- $\beta_{2}$ has a protective effect on corneal grafts following PK. Further (prospective) studies are being carried out to discover whether active TGF- $\boldsymbol{\beta}_{2}$ - determined prior to $\mathrm{PK}$ - might serve as a predictive parameter for the occurrence of immune reactions.

Eye (2008) 22, 569-575; doi:10.1038/sj.eye.6703028; published online 2 November 2007

Keywords: corneal graft survival; immune reaction; keratoplasty; transforming growth factor

\section{Introduction}

Good long-term prognosis of penetrating corneal grafts has been explained by the immunological privilege of the cornea and the anterior chamber. ${ }^{1-4}$ However, corneal graft rejection is a significant complication in corneal transplantation and one of the most important reasons for graft failure. ${ }^{5,6}$

The secretion of transforming growth factor- $\beta$ (TGF- $\beta$ ) by corneal endothelial cells, cells of the trabecular meshwork, or the ciliary body has been identified to be an important factor for the maintenance of that immunological privilege. $^{7-12}$

TGF- $\beta$ is a polypeptide cytokine with inhibitory activity on T-lymphocytes, and about $80-90 \%$ of this activity in the aqueous humour is due to the isoform TGF- $\beta_{2} \cdot{ }^{13,14}$ Antisera to TGF- $\beta_{2}$ have been demonstrated to reverse the inhibitory activity of aqueous humour. ${ }^{14}$

Low levels of TGF- $\beta_{2}$, therefore, might be associated with an elevated risk for immune reactions following penetrating keratoplasty (PK). In a previous study, we found that total TGF- $\beta_{2}$ levels were similar in eyes with and without immune reactions following PK. ${ }^{15}$ However, more than $90 \%$ of total TGF- $\beta_{2}$ cannot exert its biological functions via binding to its
University Eye Hospital, Killianstr. 5, 79106 Freiburg, Germany

Correspondence: P Maier, University Eye Hospital, Killianstr. 5, 79106 Freiburg, Germany.

Tel: + 49761270 4001; Fax: +49762 2704131 .

E-mail: philip.maier@ uniklinik-freiburg.de

Received: 22 April 2007 Accepted in revised form: 2 October 2007 Published online:

2 November 2007

Commercial relationships/ financial disclosure: None. Conflict of interest: None. 
receptor as it is secreted as an inactive precursor (latent TGF- $\beta$ complex). This precursor ( $200 \mathrm{kDa}$ ) is complexed with latency-associated peptide and bound to latent TGF- $\beta$-binding protein. To activate the latent form of TGF- $\beta$, the complexed peptides need to be removed extracellularly via proteolytic cleavage. ${ }^{16}$ The exact mechanisms by which latent TGF- $\beta_{2}$ is activated physiologically are not completely understood. One model of activation has been proposed in which latent TGF- $\beta$ is released from the extracellular matrix by proteases, localised to cell surfaces, and activated for example by thrombospondin $-1^{17}$ or specific integrins. ${ }^{18}$ In previous studies, we found that total TGF- $\beta_{2}$ levels in the aqueous humour of patients with and without immune reaction are comparable ${ }^{15}$ and that in the aqueous humour, only about $2-5 \%$ of total TGF- $\beta_{2}$ are available in its activated form. ${ }^{19}$ Furthermore, we found highest levels of active TGF- $\beta_{2}$ in keratoconus patients, who have the best prognosis following $\mathrm{PK} .{ }^{20} \mathrm{We}$ therefore tested the hypothesis whether active TGF- $\beta_{2}$ is decreased in eyes with immune reaction compared to eyes without immune reaction following PK.

\section{Patients and methods}

\section{Patients}

In group I, we examined 38 cataract patients without anti-inflammatory medication and without a history of eye disease except cataract. None of the included patients suffered from glaucoma or diabetes. In this group, patients received either topical $(92.1 \%)$, retrobulbar, $(5.3 \%)$ or general anaesthesia $(2.6 \%)$.

Group II consisted of 10 patients undergoing cataract extraction following PK with no signs of an immune reaction. In this group, one patient developed secondary glaucoma and one patient developed diabetes mellitus type 2 during follow-up.

Group III comprised 10 patients following PK with a newly diagnosed endothelial immune reaction. For therapeutic reasons, irrigation of the anterior chamber with corticosteroids was done immediately in those patients. ${ }^{21}$ None of the included patients suffered from glaucoma or diabetes. For the treatment of endothelial immune reactions in $30 \%$ of cases systemic and in $100 \%$ of cases topical steroids were started before puncture of the anterior chamber.

In cases of a high-risk keratoplasty, patients received long-lasting systemic immunosuppression either with cyclosporin A (CSA) or mycophenolate mofetil (MMF), which was started immediately after surgery. This was the case in five patients of group II $(3 \times$ repeat keratoplasty, $1 \times$ herpetic keratitis, $1 \times$ acanthamoeba keratitis) and in two of group III $(1 \times$ repeat keratoplasty,
$1 \times$ herpetic keratitis). At the time of puncture of the anterior chamber, four patients $(2 \times \mathrm{CSA}, 2 \times \mathrm{MMF})$ in group II and one patient $(1 \times \mathrm{MMF})$ in group III were still on systemic immunosuppression.

Detailed information on patients in groups II and III is given in Table 1.

All invasive procedures were performed with properly obtained written informed consent in adherence to the Declaration of Helsinki for research involving human subjects. Research was approved by the local ethics committee.

\section{Penetrating keratoplasty, post-operative therapy, follow-up}

All keratoplasties were performed with mechanical trephines. To fix the grafts, we used a double-running cross-stitch suture with Nylon 10.0. ${ }^{22}$ Gentamycin ointment was administered following surgery at least until the graft was covered by a complete epithelial layer. Then, prednisolone-21-acetate $1 \%$ eye drops were given five times daily and tapered during the first five postoperative months. Systemic corticosteroids were administered for only 3 weeks post-operatively. Oral acetazolamide was administered at a daily dose of $2 \times 250 \mathrm{mg}$ for five days post-operatively. Follow-up examinations of the graft were scheduled 6 weeks, 4,12 , and 18 months post-operatively, and thereafter once a year.

High-risk cases were defined by an increased risk for immune reactions (eg having three or four quadrants with deep vascularisation, limbal-stem-cell insufficiency, severe atopic dermatitis, ${ }^{23}$ herpes-keratitis ${ }^{24,25}$ history of previous keratoplasty, or positioning of the graft close to the limbus). ${ }^{26}$

\section{Grafts}

Grafts were either kept in hypothermic storage or preserved in organ culture according to the guidelines of the European Eye Bank Association. ${ }^{27}$ Detailed graft data are provided in Table 1.

\section{Immune reactions}

In all patients of group III, endothelial immune reactions were diagnosed clinically via endothelial precipitates and stromal oedema at the slit lamp.

\section{Anterior chamber puncture}

Prior to anterior chamber puncture all eyes were rinsed with sterile solution (BSS). A paracentesis lancet was used to penetrate the cornea in an avascular peripheral 
Table 1 Grafts' and patients' data on study groups II and III

\begin{tabular}{|c|c|c|c|c|}
\hline & $\begin{array}{l}\text { Group II acceptors } \\
\qquad(\mathrm{n}=10)\end{array}$ & $\begin{array}{l}\text { Group III rejectors } \\
\qquad(\mathrm{n}=10)\end{array}$ & P-value & $\begin{array}{c}\text { Statistical } \\
\text { test }\end{array}$ \\
\hline Donor age (years) & $57.6 \pm 11.5$ & $53.0 \pm 22.0$ & 0.57 & $t$-test \\
\hline Interval from death to graft excision (h) ${ }^{\mathrm{a}}$ & $32.4 \pm 14.6$ & $18.2 \pm 11.7$ & 0.03 & $t$-test \\
\hline Kind of graft storage & & & 0.14 & $\chi^{2}$ test \\
\hline Organ culture (\%) & 90 & 50 & & \\
\hline Hypothermic storage (\%) & 10 & 50 & & \\
\hline Duration of organ culture (days) & $20.4 \pm 7.5$ & $21.4 \pm 5.4$ & 0.81 & $t$-test \\
\hline Graft diameter $(\mathrm{mm})$ & $7.99 \pm 0.22$ & $8.05 \pm 0.47$ & 0.72 & $t$-test \\
\hline $\begin{array}{l}\text { Preoperative cell density of the graft } \\
\text { (cells } / \mathrm{mm}^{2} \text { ) }\end{array}$ & $2485 \pm 303$ & $2380 \pm 142$ & 0.49 & $t$-test \\
\hline Recipient age (years) & $55 \pm 7.8$ & $57.2 \pm 18.4$ & 0.73 & $t$-test \\
\hline Patient sex (female) & 60 & 60 & 1 & $\chi^{2}$ test \\
\hline \multicolumn{5}{|l|}{ Diagnosis leading to $P K$} \\
\hline Fuchs' dystrophy (\%) & 30 & 50 & & \\
\hline Keratoconus $(\%)$ & 10 & 10 & & \\
\hline Herpetic keratitis $(\%)$ & 10 & 10 & 0.60 & $\chi^{2}$ test \\
\hline Bulluos keratopathy (\%) & 0 & 10 & & \\
\hline Corneal dystrophy & 0 & 10 & & \\
\hline Acanthameba keratitis (\%) & 10 & 0 & & \\
\hline Corneal scar $(\%)$ & 10 & 0 & & \\
\hline Repeat keratoplasty (\%) & 30 & 10 & & \\
\hline \multicolumn{5}{|l|}{ Anesthesia } \\
\hline General (\%) & 20 & 0 & 0.31 & $\chi^{2}$ test \\
\hline Retrobulbar (\%) & 30 & 30 & & \\
\hline Topical (\%) & 50 & 70 & & \\
\hline Percentage of high-risk PK & 50 & 20 & 0.35 & $\chi^{2}$ test \\
\hline Whole follow-up period after PK (days) & $941.9 \pm 469.1$ & $1063.3 \pm 396.4$ & 0.54 & $t$-test \\
\hline $\begin{array}{l}\text { Follow-up after anterior-chamber puncture } \\
\text { (days) }\end{array}$ & $515.9 \pm 162.5$ & $534.1 \pm 80.5$ & 0.76 & $t$-test \\
\hline $\begin{array}{l}\text { Time period between PK and anterior- } \\
\text { chamber puncture (days) }\end{array}$ & $426.0 \pm 446.0$ & $529.2 \pm 400.7$ & 0.59 & $t$-test \\
\hline Ratio with systemic steroids at puncture (\%) & 0 & 30 & 0.21 & $\chi^{2}$ test \\
\hline Ratio with only topical steroids at puncture $(\%)^{\mathrm{a}}$ & 50 & 100 & 0.04 & $\chi^{2}$ test \\
\hline Ratio with antibiotics at puncture (\%) & 20 & 20 & 1 & $\chi^{2}$ test \\
\hline Ratio with systemic immunosuppression (CSA or & 40 & 10 & 0.23 & $\chi^{2}$ test \\
\hline \multicolumn{5}{|l|}{ MMF) at puncture (\%) } \\
\hline CSA & 20 & 0 & & \\
\hline MMF & 20 & 10 & & \\
\hline $\begin{array}{l}\text { Incidence of immune reactions following } \\
\text { puncture }(\%)\end{array}$ & 0 & 20 & 0.45 & $\chi^{2}$ test \\
\hline Ratio of clear grafts in whole follow-up (\%) & 100 & 70 & 0.21 & $\chi^{2}$ test \\
\hline
\end{tabular}

$\mathrm{PK}=$ keratoplasty.

${ }^{\mathrm{a}} \mathrm{P}<0.05$.

area over a length of $1 \mathrm{~mm}$. Contact with limbal or peripheral corneal vessels was completely avoided. If there was any bleeding observed, the sample was not used for further analysis. Aqueous humour $(0.05-0.1 \mathrm{ml})$ was drawn into conventional tuberculine syringes without coming into contact with intraocular structures. Following this puncture, surgery was continued as usual.
In cases of IR irrigation of the anterior chamber with steroids followed.

\section{Determination of active TGF- $\beta_{2}$}

The concentration of active TGF- $\beta_{2}$ in the aqueous humour was determined by using a Sandwich-ELISA 
(DuoSet Elisa Development Kit, human TGF- $\beta_{2}$, R\&D Systems Europe, Wiesbaden, Germany) within $3 \mathrm{~h}$ following puncture. Until determination by ELISA, all samples were kept at $4^{\circ} \mathrm{C}$. ELISA was handled according to the manufacturer's manual except that the sample volume and the concentrations of the capture and the detection antibodies were modified. Because each sample volume was barely above $100 \mu \mathrm{l}, 50 \mu \mathrm{l}$ of each sample were diluted 1:2 with the reagent diluent and determined afterwards. The concentration of the capture antibody used was $4 \mu \mathrm{g} / \mathrm{ml}$, and of the detection antibody was $200 \mathrm{ng} / \mathrm{ml}$. The sensitivity of that ELISA was $14 \mathrm{pg} / \mathrm{ml}$ of active TGF- $\beta_{2}$. Therefore, concentrations below $14 \mathrm{pg} / \mathrm{ml}$ were regarded as $0 \mathrm{pg} / \mathrm{ml}$. Optical density was read using an automated platereader (GENios, Tecan, Crailsheim, Germany) with a $450 \mathrm{~nm}$ filter. Concentrations were calculated using Magellan software (Tecan). Due to small sample volumes, an additional determination of total TGF- $\beta_{2}$ following acidic activation was not possible.

\section{Statistical analysis}

Statistical evaluation was performed using SSPS 11.0 for Windows. The paired $t$-test, $\chi^{2}$ and ANOVA were used. Correlations were determined with the Pearson's correlation coefficient. $P$-values $<0.05$ were regarded as statistically significant.

\section{Results}

Average active TGF- $\beta_{2}$ concentration was $39.9 \mathrm{pg} /$ $\mathrm{ml} \pm 24.3$ (median $41.1 \mathrm{pg} / \mathrm{ml}$ ) in group $\mathrm{I}, 46.7 \mathrm{pg} / \mathrm{ml} \pm$ 21.9 (median $45.2 \mathrm{pg} / \mathrm{ml}$ ) in group II, and $12.7 \mathrm{pg} / \mathrm{ml} \pm 26.0$ (median $0 \mathrm{pg} / \mathrm{ml}$ ) in group III. The differences between groups I and III ( $P=0.005$, ANOVA), and groups II and III ( $P=0.008$, ANOVA) were statistically significant (Figure 1).

The group of acceptors (II) consisted of 10 patients with the average concentration of active TGF- $\beta_{2}$ being above the detection level in 9 of 10 measurements, whereas active TGF- $\beta_{2}$ levels in the aqueous humour of the 10 patients in group III with newly diagnosed immune reaction was below the sensitivity value of the ELISA in $70 \%$ of cases.

As active TGF- $\beta_{2}$ levels in the aqueous humour decrease with age (26), we performed a two-factorial ANOVA to confirm the difference between group III and groups I and II by monitoring age as a potential confounding factor, and still found a statistically significant difference ( $P<0.01$, ANOVA).

There were no significant correlations between gender and levels of active TGF- $\beta_{2}$.

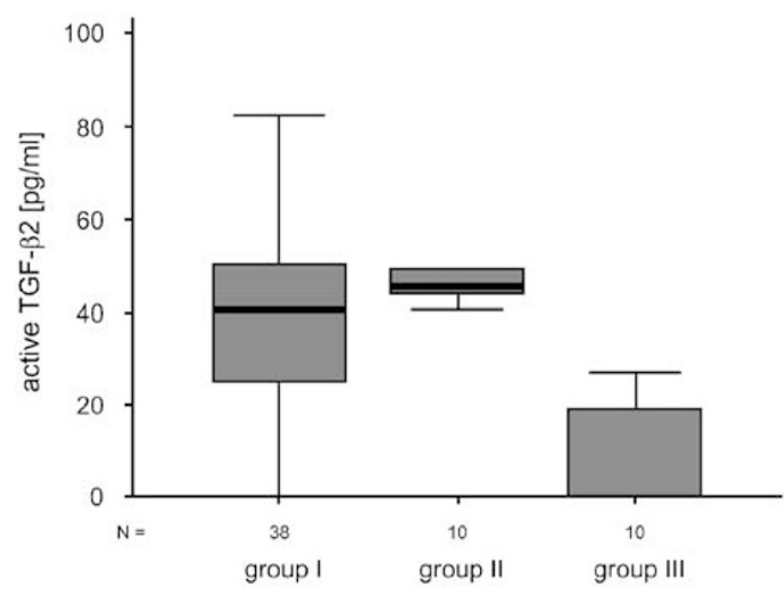

Figure 1 Active TGF- $\beta_{2}$ prior to cataract surgery (group I, $n=38$, average active TGF- $\beta_{2}$ concentration $39.9 \mathrm{pg} / \mathrm{ml} \pm 24.3$ ) and following penetrating keratoplasty without endothelial immune reaction (group II, $n=10$, average active TGF- $\beta_{2}$ concentration $46.7 \mathrm{pg} / \mathrm{ml} \pm 21.9)$ as well as with endothelial immune reaction (group III, $n=10$, average active TGF- $\beta_{2}$ concentration $12.7 \mathrm{pg} / \mathrm{ml} \pm 26.0$ ). The differences between group III and groups I $(P=0.005$, ANOVA $)$ and II $(P=0.008$, ANOVA $)$ were statistically significant. Box plot diagrams given as median values, $25 / 75 \%$ percentiles (boxes), 10/90\% percentiles (bars), and outliers (circles) of TGF- $\beta_{2}$ levels.

We could not find statistically significant differences for various grafts' properties with potential influence on post-operative endothelial cell density between groups II and III. However, in group III, the time from death to corneoscleral excision was significantly lower than in group II ( $P=0.03$, $t$-test $)$.

Regarding clinical attributes, we found a statistically significant difference for the ratio of patients with topical steroids at the time of puncture with significantly more patients in group III being treated with topical steroids $\left(P=0.04, \chi^{2}\right.$ test $)$.

We did not find a statistically significant correlation for the time period between $\mathrm{PK}$ and puncture of the anterior chamber and the levels of active TGF- $\beta_{2}$ in groups II and III ( $r=-0.05, P=0.89$ for group II, $r=-0.06, P=0.86$ for group III, Pearson's correlation).

All patients' and grafts' data are summarised in Table 1.

Had the sensitivity value $(14 \mathrm{pg} / \mathrm{ml})$ of the ELISA used for these analyses been set at $14 \mathrm{pg} / \mathrm{ml}$ instead of $0 \mathrm{pg} / \mathrm{ml}$, it would have made no statistical differences to the results presented here.

\section{Discussion}

TGF- $\beta_{2}$ has been identified as a major factor maintaining the immunological privilege of the cornea and anterior chamber. ${ }^{1-4}$ In a previous study, however, similar levels 
of total TGF- $\beta_{2}$ were observed in eyes with and without endothelial immune reactions following PK. ${ }^{15}$ Therefore, in this study, we determined levels of active TGF- $\beta_{2}$ in the aqueous humour of patients with and without immune reaction following PK. As we could show that cryopreservation of aqueous humour increases active TGF- $\beta_{2}$ levels probably due to partial activation of TGF- $\beta_{2}$ by freezing and thawing, ${ }^{19}$ we analysed active TGF- $\beta_{2}$ levels in all samples within $3 \mathrm{~h}$ following puncture.

Levels of active TGF- $\beta_{2}$ were statistically significantly decreased in the aqueous humour of patients suffering from an endothelial immune reaction (group III) compared to patients without immune reactions following PK (group II), whose active TGF- $\beta_{2}$ levels were similar to control patients without PK (group I).

As an endothelial immune reaction is usually accompanied by mild anterior uveitis, reduced levels of active TGF- $\beta_{2}$ might be explained by dilution due to influx into the anterior chamber as part of the breakdown of the blood-aqueous barrier. If this was the case, total protein levels and total TGF- $\beta_{2}$ levels were supposed to be decreased as well. However, we could show that total TGF- $\beta_{2}$ levels ${ }^{15}$ as well as total protein levels (unpublished data) are comparable in the aqueous humour of patients with and without immune reaction. Furthermore, Min et $a l^{28}$ found that active TGF- $\beta_{2}$ levels were normal in patients with uveitic secondary glaucoma. Therefore, decreased active TGF- $\beta_{2}$ levels during an endothelial immune reaction do not seem to be a simple result of an intraocular inflammation but a result of an immunological process in the anterior ocular segment.

Yamamoto et $a l^{29}$ reported that there is a negative association between TGF- $\beta_{2}$ levels and age with older patients having lower concentrations of TGF- $\beta_{2}$ in the aqueous humour. Nevertheless, statistical analysis revealed significantly lower active TGF- $\beta_{2}$ levels in patients suffering from an endothelial immune reaction compared to those without immune reaction when correcting for age as a confounding factor is done.

In this study, patients with a newly diagnosed endothelial immune reaction received statistically significant more topical steroids at the time of puncture than patients without endothelial immune reaction. On the one hand, topical or systemic steroids might reduce levels of active TGF- $\beta_{2}$ in the aqueous humour as it could be shown that locally produced hydrocortisone and corticosterone inhibited the proliferation of a TGF- $\beta_{2^{-}}$ sensitive cell line in vitro. ${ }^{30}$ On the other hand, Wallentin and Lundberg ${ }^{31}$ found that topical steroid treatment did not reduce levels of bFGF and active TGF- $\beta$ in rats following cataract extraction. Furthermore, Wakefield et $a l^{32}$ reported that members of the steroid hormone family are able to increase TGF- $\beta_{1}$ levels probably by regulating the translatability of TGF- $\beta_{1}$ mRNA or by post-translational processing events. A significant fraction (25-90\%) of the induced TGF- $\beta$ was in its biologically active rather than in its latent form. They concluded that the use of members of the steroid hormone superfamily might even have therapeutic potential by inducing TGF- $\beta$ as an immunosuppressive growth inhibitor. Whether topical or systemic steroid treatment has a direct influence on active TGF- $\beta_{2}$ levels in the aqueous humour has to be investigated in further studies.

Patients in group II received more systemic immunosuppression (20\% CSA, 20\% MMF) compared to patients in group III (10\% MMF). However, the difference was not statistically significant. The reason why patients in group II received more systemic immunosuppression than in group III, was that in this group, more high-risk keratoplasties were performed where systemic immunosuppression with CSA or MMF was started in the first place (see Table 1). Within group II, we could not find a statistically significant difference for TGF- $\beta_{2}$ levels between patients with or without systemic immunosuppression (median $48.3 \mathrm{pg} / \mathrm{ml}$ vs $44.4 \mathrm{pg} / \mathrm{ml}$, respectively). However, sample size is small and an effect of systemic immunosuppression with CSA or MMF cannot be excluded by this analysis. Therefore, further research is needed to find out whether systemic CSA or MMF might influence TGF- $\beta_{2}$ levels in the aqueous humour as there are no data in the literature covering this question until now.

Primary open-angle glaucoma has been associated with increased levels of active TGF- $\beta_{2}$ in the anterior chamber. ${ }^{33-36}$ Increased levels of active TGF- $\beta_{2}$ have been reported as well in diabetes ${ }^{28,37}$ especially following photocoagulation. ${ }^{29}$ To avoid influences on active TGF- $\beta_{2}$ levels in the aqueous humour by these frequently accompanying diseases, we decided at the beginning of this study that glaucoma and diabetes were exclusion criteria. However, during follow-up in group II, one patient developed secondary glaucoma and one patient developed diabetes mellitus type II. As we found comparable TGF- $\beta_{2}$ levels in group II and in the control group (group I), a significant effect of these two cases with diseases potentially increasing TGF- $\beta_{2}$ levels seems to be unlikely.

The time from death to corneoscleral excision was statistically significantly lower for grafts transplanted in group III compared to those in group II. This might have a positive influence on the chronic endothelial cell loss following PK in group III. ${ }^{38}$ Furthermore, there was a difference for the kind of graft storage. In group II, more grafts were kept in hypothermic storage compared to group II (90 vs 50\%, respectively). However, death to corneoscleral excision time and the storage method have 
never been reported to be correlated to an increased risk for the occurrence of endothelial immune reactions. On contrary, a loss of Langerhans cells has been observed during storage of corneal transplants, which was independent from preservation medium (organ culture or hypothermic storage) and preservation time. ${ }^{39}$ Therefore, these grafts' attributes should neither influence active TGF- $\beta_{2}$ levels in the aqueous humour nor increase the frequency of immune reactions following PK.

In corneal transplantation, immune reactions mostly occur between 12 and 24 months following $\mathrm{PK}^{40,41}$ and afterwards endothelial immune reactions are rarely observed. Therefore, during this time, an immunosuppressive environment in the anterior chamber is exceptionally important, which could be maintained by high levels of active TGF- $\beta_{2}$. One could speculate that levels of active TGF- $\beta_{2}$ decrease with time following PK as the host might develop some kind of graft-induced tolerance to the donor tissue. If this assumption was correct, higher levels of active TGF- $\beta_{2}$ prior to PK would lead to better clear graft survival. This is furthermore supported by the fact that we found highest levels of active TGF- $\beta_{2}$ in keratoconus patients, who have the best prognosis following PK. ${ }^{20}$ We received samples of patients from group II (426.0 \pm 446.0 days) about 100 days earlier than those from group III (529.2 \pm 400.7 days). This might have an influence on active TGF- $\beta_{2}$ levels in the aqueous humour. However, the difference in follow-up time was not statistically significant $(P=0.59, t$-test). Furthermore, we could not find a statistically significant correlation for the time period between $\mathrm{PK}$ and puncture of the anterior chamber and active TGF- $\beta_{2}$ levels, but small sample size of only 10 patients in each group has to be considered. So, further studies are necessary, to find out if there is a decrease of active TGF- $\beta_{2}$ over time following PK.

Besides total or active TGF- $\beta_{2}$, various factors are involved in the maintenance and regulation of the immunological privilege of the anterior chamber, which have to be investigated in future studies.

Thrombospondin, for example, is a potent physiologic regulator of TGF- $\beta$ activation ${ }^{42}$ and somatostatin ${ }^{43}$ as well as $\alpha$-melanocyte stimulating hormone ${ }^{44}$ have been identified as important regulators of the anterior chamber associated immune deviation.

The findings of this study might be interpreted as hinting at a primarily altered immunological privilege in eyes that develop immune reactions following PK. The question thus arises whether only eyes with decreased TGF- $\beta_{2}$ levels develop endothelial immune reactions following PK. If that is the case, active TGF- $\beta_{2}$ might serve as a predictive parameter if determined prior to PK. Then, decreased TGF- $\beta_{2}$ levels should force the surgeon to administer effective (topical and/or systemic) immunomodulative measures in the long run. This has to be found out in further prospective studies with longlasting clinical follow-up.

\section{Acknowledgements}

We acknowledge with gratitude the late Professor Wayne Streilein, whose advice and assistance in conceiving this study was invaluable. This study was supported by a grant from the Deutsche Forschungsgemeinschaft (DFG, RE 1382/5-1).

\section{References}

1 Callanan D, Peeler J, Niederkorn JY. Characteristics of rejection of orthotopic corneal allografts in the rat. Transplantation 1988; 45(2): 437-443.

2 Niederkorn JY. The induction of anterior chamberassociated immune deviation. Chem Immunol Allergy 2007; 92: $27-35$

3 Streilein JW. Unraveling immune privilege. Science 1995; 270(5239): 1158-1159.

4 Yamada J, Streilein JW. Induction of anterior chamberassociated immune deviation by corneal allografts placed in the anterior chamber. Invest Ophthalmol Vis Sci 1997; 38(13): 2833-2843.

5 Williams KA, Muehlberg SM, Lewis RF, Coster DJ. How successful is corneal transplantation? A report from the Australian Corneal Graft Register. Eye 1995; 9(Part 2): 219-227.

6 Claesson M, Armitage WJ, Fagerholm P, Stenevi U. Visual outcome in corneal grafts: a preliminary analysis of the Swedish Corneal Transplant Register. Br J Ophthalmol 2002; 86(2): 174-180.

7 Kawashima H, Prasad SA, Gregerson DS. Corneal endothelial cells inhibit T cell proliferation by blocking IL-2 production. J Immunol 1994; 153(5): 1982-1989.

8 Knisely TL, Bleicher PA, Vibbard CA, Granstein RD. Production of latent transforming growth factor-beta and other inhibitory factors by cultured murine iris and ciliary body cells. Curr Eye Res 1991; 10(8): 761-771.

9 Peress NS, Perillo E. TGF-beta 2 and TGF-beta 3 immunoreactivity within the ciliary epithelium [corrected]. Invest Ophthalmol Vis Sci 1994; 35(2): 453-457.

10 Tripathi RC, Chan WF, Li J, Tripathi BJ. Trabecular cells express the TGF-beta 2 gene and secrete the cytokine. Exp Eye Res 1994; 58(5): 523-528.

11 Sano Y, Okamoto S, Streilein JW. Induction of donor-specific ACAID can prolong orthotopic corneal allograft survival in 'high-risk' eyes. Curr Eye Res 1997; 16(11): 1171-1174.

12 Wilson SE, Lloyd SA. Epidermal growth factor and its receptor, basic fibroblast growth factor, transforming growth factor beta-1, and interleukin-1 alpha messenger RNA production in human corneal endothelial cells. Invest Ophthalmol Vis Sci 1991; 32(10): 2747-2756.

13 Link H XB. Transforming Growth Factor $\beta$, Vol. 2nd ed Academic Press, San Diego, 1998 pp 2392-2399.

14 Cousins SW, McCabe MM, Danielpour D, Streilein JW. Identification of transforming growth factor-beta as an 
immunosuppressive factor in aqueous humor. Invest Ophthalmol Vis Sci 1991; 32(8): 2201-2211.

15 Reinhard T, Bonig H, Mayweg S, Bohringer D, Gobel U, Sundmacher R. Soluble Fas ligand and transforming growth factor beta2 in the aqueous humor of patients with endothelial immune reactions after penetrating keratoplasty. Arch Ophthalmol 2002; 120(12): 1630-1635.

16 Khalil N. TGF-beta: from latent to active. Microbes Infect 1999; 1(15): 1255-1263.

17 Zamiri P, Masli S, Kitaichi N, Taylor AW, Streilein JW. Thrombospondin plays a vital role in the immune privilege of the eye. Invest Ophthalmol Vis Sci 2005; 46(3): 908-919.

18 Neurohr C, Nishimura SL, Sheppard D. Activation of transforming growth factor-beta by the integrin alphavbeta8 delays epithelial wound closure. Am J Respir Cell Mol Biol 2006; 35(2): 252-259.

19 Maier P, Broszinski A, Heizmann U, Boehringer D, Reinhard T. Determination of active TGF-beta 2 in aqueous humor prior to and following cryopreservation. Mol Vis 2006; 12: 1477-1482.

20 Maier P, Broszinski A, Heizmann U, Boehringer D, Reinhard T. Active transforming growth factor-beta2 is increased in the aqueous humor of keratoconus patients. Mol Vis 2007; 13: 1198-1202.

21 Reinhard T, Sundmacher R. Adjunctive intracameral application of corticosteroids in patients with endothelial immune reactions after penetrating keratoplasty: a pilot study. Transpl Int 2002; 15(2-3): 81-88.

22 Hoffmann F. [Suture technique for perforating keratoplasty (author's transl)]. Klin Monatsbl Augenheilkd 1976; 169(5): 584-590.

23 Reinhard T, Bohringer D, Huschen D, Sundmacher R. [Chronic endothelial cell loss of the graft after penetrating keratoplasty: influence of endothelial cell migration from graft to host]. Klin Monatsbl Augenheilkd 2002; 219(6): 410-416.

24 Mayer K, Reinhard T, Reis A, Voiculescu A, Sundmacher R. Synergistic antiherpetic effect of acyclovir and mycophenolate mofetil following keratoplasty in patients with herpetic eye disease: first results of a randomised pilot study. Graefes Arch Clin Exp Ophthalmol 2003; 241(12): 1051-1054.

25 Reis A, Reinhard T, Voiculescu A, Kutkuhn B, Godehardt E, Spelsberg $\mathrm{H}$ et al. Mycophenolate mofetil versus cyclosporin A in high risk keratoplasty patients: a prospectively randomised clinical trial. Br J Ophthalmol 1999; 83(11): 1268-1271.

26 Reinhard T, Sundmacher R, Godehardt E, Heering P. [Preventive systemic cyclosporin A after keratoplasty at increased risk for immune reactions as the only elevated risk factor]. Ophthalmologe 1997; 94(7): 496-500.

27 Alvarez de Toledo J, Armitage WJ, Ponzin D, Tullo A. EEBA standards 2007. http://www.europeaneyebanks.org/ public/_cfm/page/page_471.cfm.

28 Min SH, Lee TI, Chung YS, Kim HK. Transforming growth factor-beta levels in human aqueous humor of glaucomatous, diabetic and uveitic eyes. Korean J Ophthalmol 2006; 20(3): 162-165.

29 Yamamoto N, Itonaga K, Marunouchi T, Majima K. Concentration of transforming growth factor beta2 in aqueous humor. Ophthalmic Res 2005; 37(1): 29-33.
30 Knisely TL, Hosoi J, Nazareno R, Granstein RD. The presence of biologically significant concentrations of glucocorticoids but little or no cortisol binding globulin within aqueous humor: relevance to immune privilege in the anterior chamber of the eye. Invest Ophthalmol Vis Sci 1994; 35(10): 3711-3723

31 Wallentin N, Lundberg C. Steroid and anti-CD18 treatment have no effect on after-cataract formation following surgery in rabbits. Curr Eye Res 2000; 20(5): 384-393.

32 Wakefield L, Kim SJ, Glick A, Winokur T, Colletta A, Sporn M. Regulation of transforming growth factor-beta subtypes by members of the steroid hormone superfamily. J Cell Sci Suppl 1990; 13: 139-148.

33 Tripathi RC, Li J, Chan WF, Tripathi BJ. Aqueous humor in glaucomatous eyes contains an increased level of TGF-beta 2. Exp Eye Res 1994; 59(6): 723-727.

34 Inatani M, Tanihara H, Katsuta H, Honjo M, Kido N, Honda Y. Transforming growth factor-beta 2 levels in aqueous humor of glaucomatous eyes. Graefes Arch Clin Exp Ophthalmol 2001; 239(2): 109-113.

35 Picht G, Welge-Luessen U, Grehn F, Lutjen-Drecoll E. Transforming growth factor beta 2 levels in the aqueous humor in different types of glaucoma and the relation to filtering bleb development. Graefes Arch Clin Exp Ophthalmol 2001; 239(3): 199-207.

36 Wimmer I, Welge-Luessen U, Picht G, Grehn F. Influence of argon laser trabeculoplasty on transforming growth factorbeta 2 concentration and bleb scarring following trabeculectomy. Graefes Arch Clin Exp Ophthalmol 2003; 241(8): 631-636.

37 Ochiai Y, Ochiai H. Higher concentration of transforming growth factor-beta in aqueous humor of glaucomatous eyes and diabetic eyes. Jpn J Ophthalmol 2002; 46(3): 249-253.

38 Bohringer D, Reinhard T, Spelsberg H, Sundmacher R. Influencing factors on chronic endothelial cell loss characterised in a homogeneous group of patients. $\mathrm{Br} \mathrm{J}$ Ophthalmol 2002; 86(1): 35-38.

39 Ardjomand N, Berghold A, Reich ME. Loss of corneal Langerhans cells during storage in organ culture medium, Optisol and McCarey-Kaufman medium. Eye 1998; 12 (Part 1): 134-138.

40 Kuchle M, Cursiefen C, Nguyen NX, Langenbucher A, Seitz $\mathrm{B}$, Wenkel $\mathrm{H}$ et al. Risk factors for corneal allograft rejection: intermediate results of a prospective normal-risk keratoplasty study. Graefes Arch Clin Exp Ophthalmol 2002; 240(7): 580-584.

41 Smiddy WE, Stark WJ, Young E, Klein PE, Bias WD, Maumenee AE. Clinical and immunological results of corneal allograft rejection. Ophthalmic Surg 1986; 17(10): 644-649.

42 Schultz-Cherry S, Murphy-Ullrich JE. Thrombospondin causes activation of latent transforming growth factor-beta secreted by endothelial cells by a novel mechanism. J Cell Biol 1993; 122(4): 923-932.

43 Taylor AW, Yee DG. Somatostatin is an immunosuppressive factor in aqueous humor. Invest Ophthalmol Vis Sci 2003; 44(6): 2644-2649.

44 Taylor AW, Streilein JW, Cousins SW. Identification of alphamelanocyte stimulating hormone as a potential immunosuppressive factor in aqueous humor. Curr Eye Res 1992; 11(12): 1199-1206. 